\section{Proton pump inhibitors and gastric cancer: a long expected side effect finally reported also in man}

We read with interest the report by Cheung et al describing increased risk of gastric cancer in patients treated long-term proton pump inhibitor (PPI) after Helicobacter pylori eradication. ${ }^{1}$ On the same day, a Swedish study also reported increased risk of gastric cancer in patients having been treated long-term with PPI. ${ }^{2}$ Since cancers in general most often require decades to develop, the magnitude of the PPI-related cancer risk cannot be foreseen. For 30 years, we have worked with the role of gastrin and the risk of PPI treatment with respect to gastric cancer and published more than 200 papers and letters in this field. However, our publications have for one reason or the other been overseen and not discussed. On the other hand, since we always have concluded that PPI treatment in the long term would cause gastric cancer, it is strange that producers of PPIs have not done studies to dismiss our results. However, the gastric cancer risk linked to PPI treatment should have been anticipated as early as in the late 1980s.

Around 1980, it became clear that hypergastrinemia, either due to gastrinoma in MEN1 patients with increased gastric acid secretion or secondary to atrophic gastritis with gastric hypoacidity, resulted in ECL cell neuroendocrine tumours. Bordi asked whether they were hormonally induced. The interest for such tumours increased dramatically when PPIs as well as the insurmountable histamine-2 blocker loxtidine caused ECL cell tumours in the rat. ${ }^{3}$ Glaxo then stopped developing loxtidine, whereas Astra continued with omeprazole in clinical trials. At meetings arranged by the PPI manufacturer, with most experts within gastric pathology and gastroenterology present, it was concluded that the ECL cell did not play any appreciable role in human gastric carcinogenesis. Omeprazole was accepted for use in patients with severe diseases due to gastric acid hypersecretion. However, PPIs were soon used in less severe cases and are now prescribed to patients with minor complaints from the upper abdomen (10\% of the population in the Western world).

We recall Kenneth Wormsley's words about the acceptance of omeprazole for clinical use: "The first compound accepted for use in humans after having induced cancer in its target organ"; a taboo was broken. Moreover, the claim that the ECL cell was insignificant in gastric carcinogenesis was flawed. ECL derived gastric carcinomas had been described already in the late 1970s. It was also evident that the distinction between adenocarcinomas and neuroendocrine carcinomas was difficult in both humans ${ }^{4}$ and rodents. In rodents, we demonstrated that the gastrin receptor was localised to the ECL cell and not to the parietal $\mathrm{cell}^{5}$ and that gastrin stimulated ECL cell histamine release and proliferation at rather low concentrations. We then turned to pathology, and by using the most specific and sensitive methods available to study ECL cell markers in gastric carcinomas, we found such differentiation particularly in carcinomas classified as diffuse according to Lauren, ${ }^{6-8}$ notably in almost all carcinomas from patients with pernicious anaemia displayed ECL cell markers.

Early, it was recognised that PPIs induced hypergastrinemia and ECL cell hyperplasia. ${ }^{9}$ In a proportion of patients, gastrin was found to be elevated, but most often, only slightly. It must be recalled that blood gastrin measured 24 hours after the last PPI intake is a trough value and that the 24 hours integral is far more important with regard to ECL cell proliferation. Like in the rat, where the tumorigenesis starts with hyperplasia and then develops into neoplasia of increasing malignancy, the same initial event was found in man. It therefore seems naïve to believe that the process halts in man, whereas it continues only in the rat. All processes take less time in short-lived animals compared with man.

Recently, a study from Finland found that patients with high gastrin values in samples from the eighties had increased risk of gastric cancer, ${ }^{10}$ and we have proposed 
that even the carcinogenic effect of $H$. pylori infection is best explained by the hypergastrinemia secondary to oxyntic atrophy.

We conclude that the carcinogenic effect by PPI treatment is due to hypergastrinemia, which should have been realised decades ago before exposing so many patients to a risk of a serious disease.

Helge Lyder Waldum, ${ }^{1,2}$ Reidar Fossmark ${ }^{1,2}$

${ }^{1}$ Department of Clinical and Molecular Medicine, Norwegian University of Science and Technology, Trondheim, Norway

${ }^{2}$ Department of Gastroenterology and Hepatology, St Olavs Hospital, Trondheim, Norway

Correspondence to Professor Helge Lyder Waldum, Department of Clinical and Molecular, University of Science and Technology, Trondheim, Norway; helge. waldum@ntnu.no

Contributors The two authors have written, revised and approved the letter.

Competing interests None declared.

Provenance and peer review Not commissioned; internally peer reviewed.

\section{6 OPEN ACCESS}

Open Access This is an Open Access article distributed in accordance with the Creative Commons
Attribution Non Commercial (CC BY-NC 4.0) license, which permits others to distribute, remix, adapt, build upon this work non-commercially, and license their derivative works on different terms, provided the original work is properly cited and the use is noncommercial. See: http://creativecommons.org/licenses/ by-nc/4.0/

(C) Article author(s) (or their employer(s) unless otherwise stated in the text of the article) 2018. All rights reserved. No commercial use is permitted unless otherwise expressly granted.

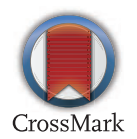

To cite Waldum HL, Fossmark R. Gut 2018;67:199-200.

Received 8 November 2017

Accepted 11 November 2017

Published Online First 20 November 2017

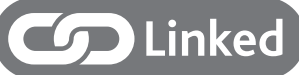

- http://dx.doi.org/10.1136/gutjnl-2017-314605

Gut 2018;67:199-200.

doi:10.1136/gutjnl-2017-315629

\section{REFERENCES}

1 Cheung KS, Chan EW, Wong AYS, et al. Long-term proton pump inhibitors and risk of gastric cancer development after treatment for Helicobacter pylori: a population-based study. Gut 2018;67:28-35.
2 Brusselaers N, Wahlin K, Engstrand L, et al. Maintenance therapy with proton pump inhibitors and risk of gastric cancer: a nationwide populationbased cohort study in Sweden. BMJ Open 2017;7:e017739.

3 Poynter D, Pick CR, Harcourt RA, et al. Association of long lasting unsurmountable histamine H2 blockade and gastric carcinoid tumours in the rat. Gut 1985;26:1284-95.

4 Wilander E, Sundström C, Grimelius L. Pernicious anaemia in association with argyrophil (SevierMunger) gastric carcinoid. Scand I Haematol 1979:23:415-20.

5 Bakke I, Qvigstad G, Sandvik AK, et al. The CCK-2 receptor is located on the $\mathrm{ECL}$ cell, but not on the parietal cell. Scand J Gastroenterol 2001;36:1128-33.

6 Qvigstad G, Sandvik AK, Brenna E, et al. Detection of chromogranin $A$ in human gastric adenocarcinomas using a sensitive immunohistochemical technique. Histochem J 2000;32:551-6.

7 Qvigstad G, Qvigstad T, Westre B, et al. Neuroendocrine differentiation in gastric adenocarcinomas associated with severe hypergastrinemia and/or pernicious anemia. APMIS 2002;110:132-9.

8 Waldum HL, Haugen OA, Isaksen C, et al. Are diffuse gastric carcinomas neuroendocrine tumours (ECL-omas)? Eur J Gastroenterol Hepatol 1991;3:245-9.

9 Lamberts R, Creutzfeldt W, Stöckmann F, et al. Long-term omeprazole treatment in man: effects on gastric endocrine cell populations. Digestion 1988;39:126-35.

10 Murphy G, Abnet CC, Choo-Wosoba H, et al. Serum gastrin and cholecystokinin are associated with subsequent development of gastric cancer in a prospective cohort of Finnish smokers. Int I Epidemiol 2017;46:914-23. 